\title{
An Experimental Investigation on Properties of Concrete by Partial Replacement of Cement with GGBS and Fine Aggregate with Quarry Dust
}

\author{
Dr. D. V. Prasada Rao ${ }^{1}$, C. S. Mallikarjuna ${ }^{2}$ \\ ${ }^{1}$ Professor, Department of Civil Engineering, Sri Venkateswara University College of Engineering, Tirupati, Andhra Pradesh, India \\ ${ }^{2}$ PG Student, Department of Civil Engineering, Sri Venkateswara University College of Engineering, Tirupati, Andhra Pradesh, India
}

\begin{abstract}
In the present study an investigation is made on properties of concrete by partial replacement of Cement with Ground Granulated Blast Furnace Slag (GGBS) and Fine Aggregate with Quarry Dust (QD). Ground Granulated Blast Furnace Slag is a byproduct of Iron and Steel industry which is produced in large quantities as a solid waste. It is highly cementitious, Quarry Dust is used as a replacement of Natural Sand due to its scarcity. The replacement percentages of Cement with GGBS are $20 \%$, $40 \%$ and $60 \%$ by weight and $25 \%, 50 \%, 75 \%$ and $100 \%$ of Quarry Dust are used as a replacement of Natural Sand. Various combinations of GGBS and Quarry Dust were prepared using M30 Grade of Concrete. The effect on these replacement materials on Compressive Strength, Split Tensile Strength, Flexural Strength, Modulus of Elasticity and Water Absorption were studied and the results obtained were compared with the Control Concrete. It is observed that the optimum replacement percentages of GGBS and Quarry Dust are 40\% and 50\% respectively.
\end{abstract}

Keywords: GGBS, Quarry Dust, Partial Replacement, Compressive Strength

\section{Introduction}

Concrete is the most widely used construction material all over the World. The constituents of Concrete are Cement, Fine Aggregate, Coarse Aggregate and water. Cement acts as a binder material for Concrete. During its production of Cement, $\mathrm{CO}_{2}$ is released into the atmosphere, which is harmful to the environment. Many researches have worked out on the ways of reducing the Cement Content which tends to the reduction in $\mathrm{CO}_{2}$ emissions. Various by-products like FlyAsh, Slica Fume, Metakaolin, GGBS were used as a replacement for Cement. In this study. GGBS is used as a replacement for Cement.

Acute shortage and high price of Natural Sand tends to find an alternative material for it. Quarry Dust is used as a replacement of Natural Sand. the disposal problems can also be reduced because of its usage in the production of Concrete.

\section{Objective}

The main aim of the present work is to determine the strength characteristics of concrete by partial replacement of cement with GGBS and Fine aggregate with Quarry Dust for application in structural concrete, which will give better understanding on the properties of concrete. The effect of GGBS and Quarry Dust (QD) on the properties of Concrete are studied.

\section{Experimental Programme}

\subsection{Properties of Materials}

\subsubsection{Cement}

The cement which is used in the present study is UltraTech Ordinary Portland Cement (OPC) of 53 grade. The properties of Cement are confirming to IS 12269-1987 Specifications.

\subsubsection{Fine Aggregate}

Fine Aggregate which is used in the study is locally available and it conforms to IS Specifications. The properties are shown in Table No.1

Table 1: Physical properties of Fine Aggregate

\begin{tabular}{|c|c|c|}
\hline S.No & Property & Result \\
\hline 1 & Specific Gravity & 2.52 \\
\hline 2 & Fineness Modulus & 3.76 \\
\hline 3 & Zone & Zone - II \\
\hline
\end{tabular}

\subsubsection{Coarse Aggregate}

Coarse aggregate of nominal size $20 \mathrm{~mm}$ and $12 \mathrm{~mm}$, obtained from the local quarry confirming to IS specifications was used. The properties of Coarse aggregate are shown in Table No.2

Table 2: Properties of Coarse Aggregate

\begin{tabular}{|c|c|c|}
\hline S.No & Property & Result \\
\hline 1 & Specific Gravity & 2.67 \\
\hline 2 & Water Absorption & $0.4 \%$ \\
\hline
\end{tabular}

3.1.4 Ground Granulated Blast Furnace Slag (GGBS) GGBS is obtained from AASTRA chemicals, Chennai. Properties of GGBS are presented in Table No.3 


\section{International Journal of Science and Research (IJSR) \\ ISSN (Online): 2319-7064}

Index Copernicus Value (2016): 79.57 | Impact Factor (2015): 6.391

\begin{tabular}{|c|c|}
\hline Characteristics & Test results \\
\hline Fineness Modulus & 3.90 \\
\hline Specific Gravity & 2.85 \\
\hline Insoluble residue & 0.49 \\
\hline
\end{tabular}

\subsubsection{Quarry Dust}

Quarry Dust is obtained from the local quarry near Chandragiri, Tirupathi , Andhra Pradesh. The properties of QD are shown in Table No.4

Table 4: Properties of Quarry Dust

\begin{tabular}{|c|c|c|}
\hline S.No & Property & Result \\
\hline 1 & Specific Gravity & 2.3 \\
\hline 2 & Fineness Modulus & 2.18 \\
\hline 3 & Water absorption & $3.5 \%$ \\
\hline
\end{tabular}

\subsubsection{Water}

The water used for casting and curing of concrete test specimens was free of acids, organic matter, suspended solids and impurities which when present can adversely affect the strength of concrete.

\subsection{Concrete Mix Proportion}

M30 grade of concrete is used in the present investigation. The mix design is done as per Indian Standard Code of Practice.

Table 5: Quantities of Ingredients per $\mathrm{m}^{3}$ of M30 Grade Concrete

\begin{tabular}{|c|c|c|c|c|c|c|c|c|c|}
\hline S.NO & Cement (\%) & QD (\%) & GGBS (\%) & $\begin{array}{c}\text { Water } \\
(\mathrm{Lit})\end{array}$ & Cement $(\mathrm{kg})$ & $\begin{array}{c}\text { QD } \\
(\mathrm{kg})\end{array}$ & $\begin{array}{c}\text { Fine Aggregate } \\
(\mathrm{kg})\end{array}$ & $\begin{array}{c}\text { GGBS } \\
(\mathrm{kg})\end{array}$ & $\begin{array}{c}\text { Coarse } \\
\text { Aggregate }(\mathrm{kg})\end{array}$ \\
\hline 1 & 100 & 0 & 0 & 165 & 375 & 0 & 778 & 0 & 1199 \\
\hline 2 & 100 & 25 & 0 & 165 & 375 & 194.5 & 583.5 & 0 & 1199 \\
\hline 3 & 100 & 50 & 0 & 165 & 375 & 389 & 389 & 0 & 1199 \\
\hline 4 & 100 & 75 & 0 & 165 & 375 & 583.5 & 194.5 & 0 & 1199 \\
\hline 5 & 100 & 100 & 0 & 165 & 375 & 778 & 0 & 0 & 1199 \\
\hline 6 & 80 & 25 & 20 & 165 & 300 & 194.5 & 583.5 & 75 & 1199 \\
\hline 7 & 80 & 50 & 20 & 165 & 300 & 389 & 389 & 75 & 1199 \\
\hline 8 & 80 & 75 & 20 & 165 & 300 & 583.5 & 194.5 & 75 & 1199 \\
\hline 9 & 80 & 100 & 20 & 165 & 300 & 778 & 0 & 75 & 1199 \\
\hline 10 & 60 & 25 & 40 & 165 & 225 & 194.5 & 583.5 & 150 & 1199 \\
\hline 11 & 60 & 50 & 40 & 165 & 225 & 389 & 389 & 150 & 1199 \\
\hline 12 & 60 & 75 & 40 & 165 & 225 & 583.5 & 194.5 & 150 & 1199 \\
\hline 13 & 60 & 100 & 40 & 165 & 225 & 778 & 0 & 150 & 1199 \\
\hline 14 & 40 & 25 & 60 & 165 & 150 & 194.5 & 583.5 & 225 & 1199 \\
\hline 15 & 40 & 50 & 60 & 165 & 150 & 389 & 389 & 225 & 1199 \\
\hline 16 & 40 & 75 & 60 & 165 & 150 & 583.5 & 194.5 & 225 & 1199 \\
\hline 17 & 40 & 100 & 60 & 165 & 150 & 778 & 0 & 225 & 1199 \\
\hline
\end{tabular}

\section{Results and Discussions}

\subsection{Compressive Strength}

The Compressive strength test carried at the age of 3,7,28 and 56days. The load is applied gradually until the specimen fails. the load at failure divided by area of the specimen gives the Compressive Strength of Concrete.

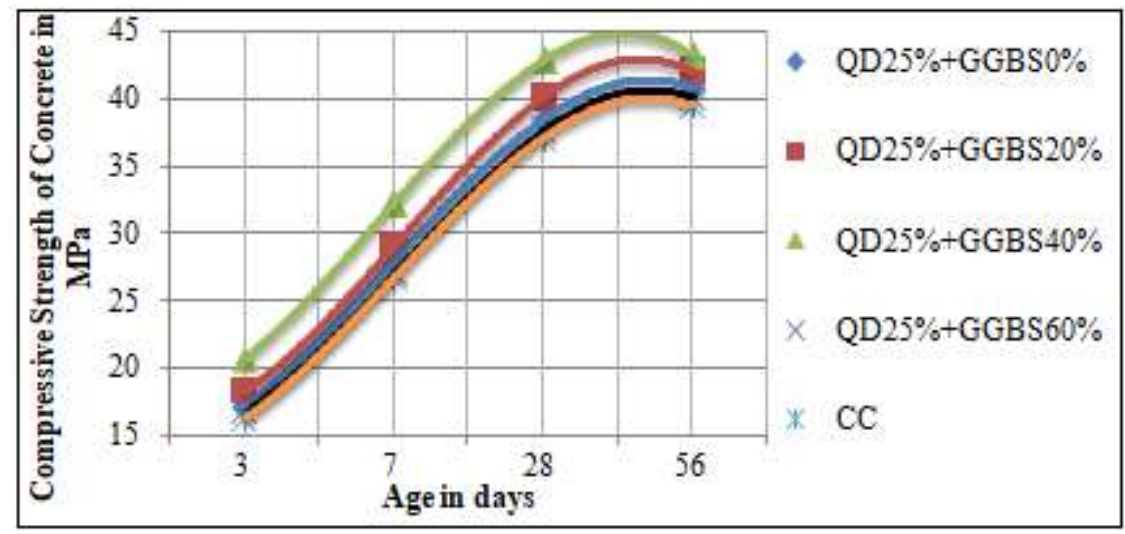

Figure 1: Compressive Strength variation at different percentages of GGBS and 25\% QD

From the graph it can be observed that the compressive strength of concrete increases with increase in age. The maximum strength occurred at a replacement of Cement by
$40 \%$ GGBS and Sand by $25 \%$ Quarry Dust. The Compressive Strength results of Concrete for other combinations of GGBS and QD are shown in Figs 2 to 4

Volume 6 Issue 12, December 2017 www.ijsr.net 


\section{International Journal of Science and Research (IJSR) \\ ISSN (Online): 2319-7064}

Index Copernicus Value (2016): 79.57 | Impact Factor (2015): 6.391

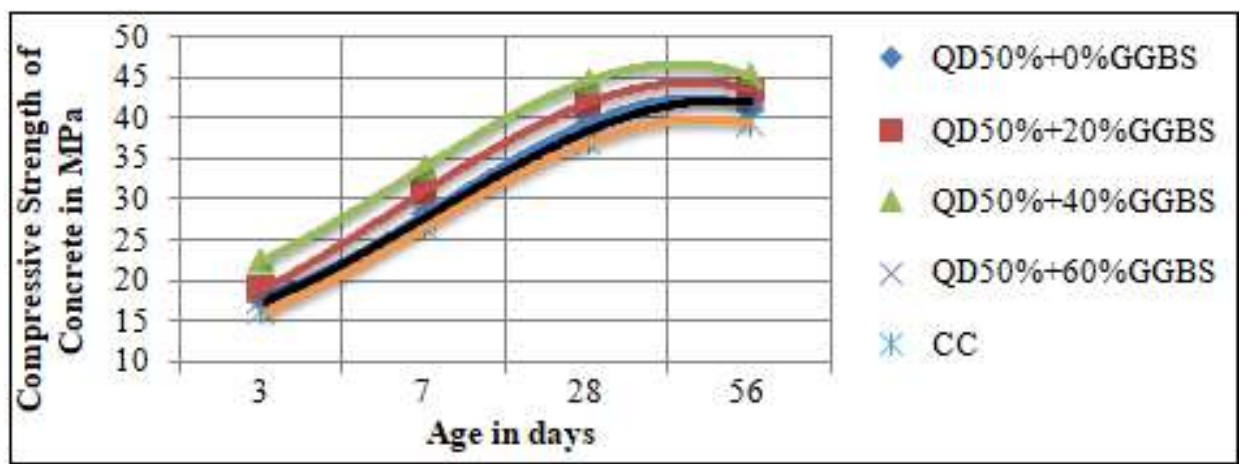

Figure 2: Compressive Strength varaiation at different percentages of GGBS and 50\% QD

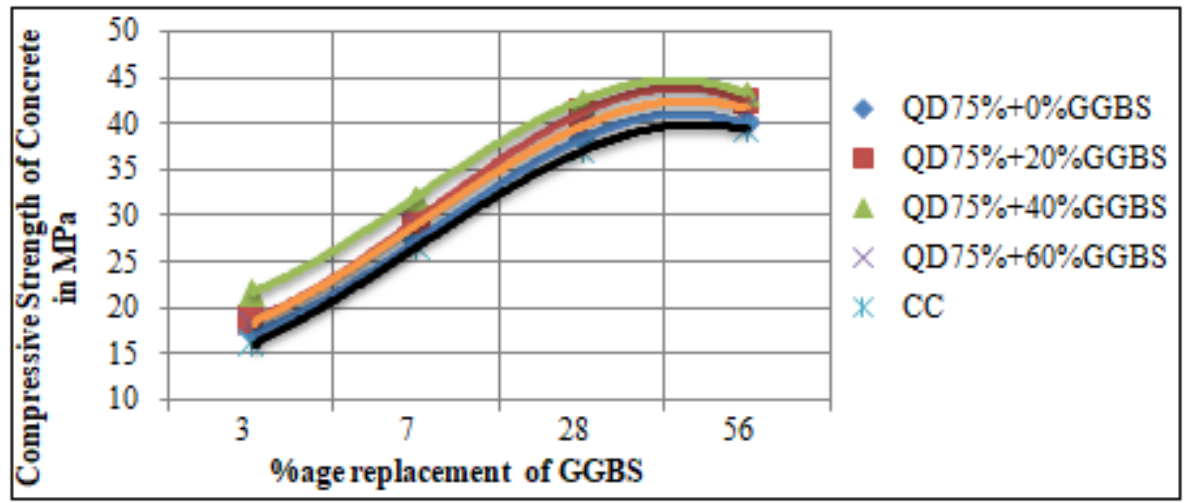

Figure 3: Compressive Strength varaiation at different percentages of GGBS and 75\% QD

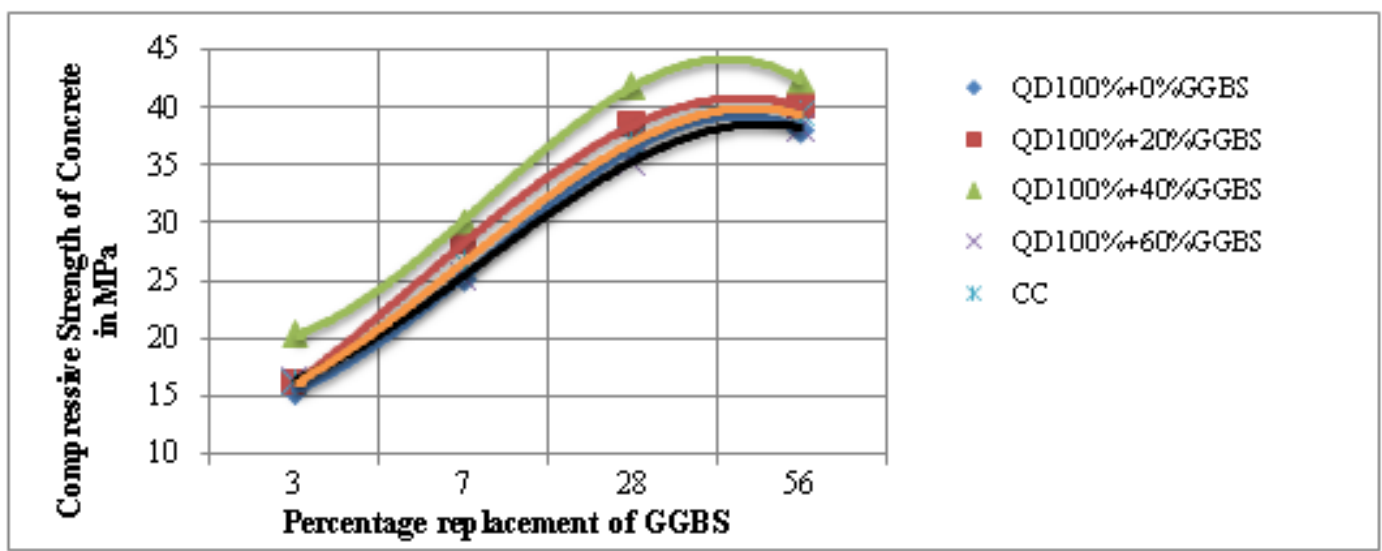

Figure 4: Compressive Strength varaiation at different percentages of GGBS and 100\% QD

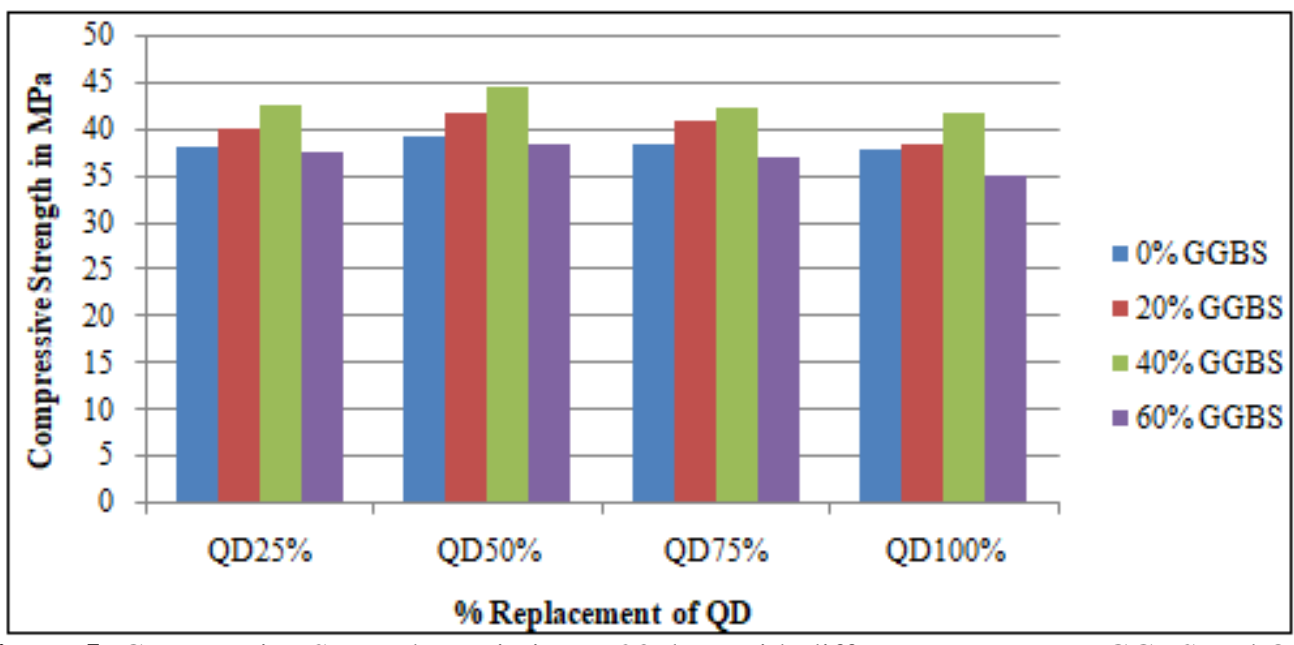

Figure 5: Compressive Strength varaiation at 28 days with different percentages GGBS and QD

Volume 6 Issue 12, December 2017 www.ijsr.net

Licensed Under Creative Commons Attribution CC BY 


\section{International Journal of Science and Research (IJSR) \\ ISSN (Online): 2319-7064 \\ Index Copernicus Value (2016): 79.57 | Impact Factor (2015): 6.391}

From the Fig.5 it is observed that the maximum strength occurred at $40 \%$ replacement of Cement with GGBS and $50 \%$ replacement of Fine Aggregate with Quarry Dust

Table 6: Percentage increase in Compressive Strength at 28 days for optimum mix proportion

\begin{tabular}{|c|c|c|}
\hline Concrete Mix & Compressive Strength (MPa) & \% Increase \\
\hline Control Concrete & 37.8 & - \\
\hline GGBS40\% + QD50\% & 44.6 & 18 \\
\hline
\end{tabular}

\subsection{Split Tensile Strength}

The variation of Split tensile Strength of Concrete obtained using cylinder specimens of size $150 \mathrm{~mm} \times 300 \mathrm{~mm}$ is shown in Fig.6

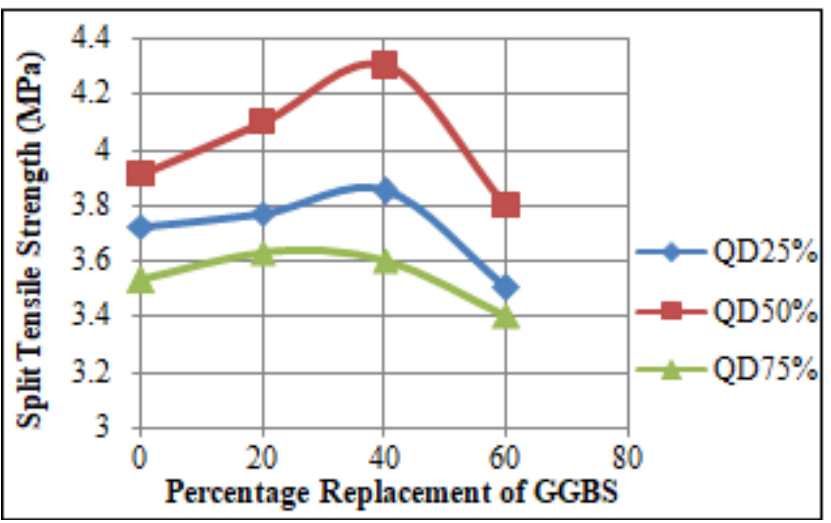

Figure 6: Split Tensile Strength variation for different percentages of GGBS and QD

From the Fig.6 it is clear that the maximum Split tensile strength of Concrete occurred at a replacement $40 \%$ GGBS and 50\% Quarry Dust. The same trend can be observed for the various combinations of GGBS and QD.

Table 7: Percentage increase in Split Tensile Strength at 28 days for optimum mix proportion

\begin{tabular}{|c|c|c|}
\hline Concrete Mix & $\begin{array}{c}\text { Split Tensile Strength } \\
\text { in MPa }\end{array}$ & $\begin{array}{c}\% \\
\text { Increase }\end{array}$ \\
\hline Control Concrete & 3.63 & - \\
\hline GGBS40\%\%+QD50\% & 4.3 & 18.4 \\
\hline
\end{tabular}

\subsection{Flexural Strength}

Flexural Strength is a measure of tensile strength of concrete prisms of size $500 \mathrm{mmx} 100 \mathrm{mmx} 100 \mathrm{~mm}$ were used. Flexural strength is also known as Modulus of Rupture. It is a measure of unreinforced concrete beam to resist failure in bending.

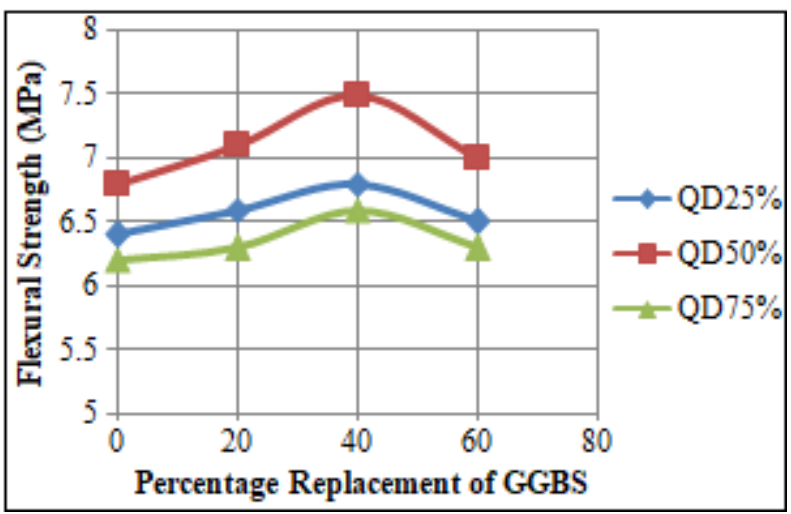

Figure 7: Split Tensile Strength variation for different percentages of GGBS and QD

The maximum flexural strength occurred at a percentage of 40\% GGBS and 50\% Quarry Dust. Beyond the maximum replacement levels the strength decreases.

Table 7: Percentage increase in Flexural Strength at 28 days for optimum mix proportion

\begin{tabular}{|c|c|c|}
\hline Concrete Mix & $\begin{array}{c}\text { Flexural Strength } \\
\text { in MPa }\end{array}$ & $\begin{array}{c}\% \\
\text { Increase }\end{array}$ \\
\hline Control Concrete & 5.8 & - \\
\hline GGBS40\%\%+QD50\% & 7.5 & 29 \\
\hline
\end{tabular}

\subsection{Modulus of Elasticity}

Modulus of Elasticity of Concrete is obtained by testing cylindrical specimens of size $300 \mathrm{mmx} 150 \mathrm{~mm}$ in Compression.

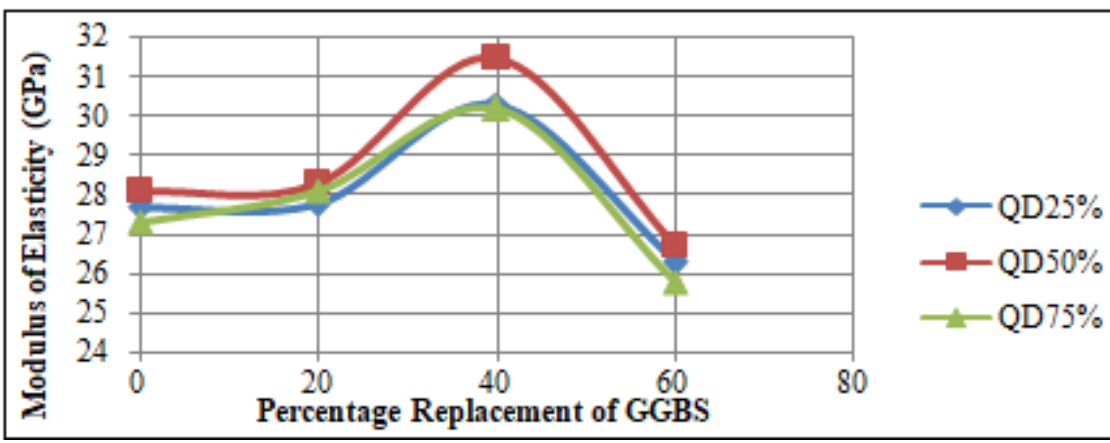

Figure 8: Modulus of Elasticity variation for different percentages of GGBS and QD

\subsection{Water Absorption}

Water Absorption test was conducted on Concrete cubes of size $150 \mathrm{mmx} 150 \mathrm{mmx} 150 \mathrm{~mm}$. The cubes were cast and tested at the age of 56 days. 


\title{
International Journal of Science and Research (IJSR) \\ ISSN (Online): 2319-7064
}

Index Copernicus Value (2016): 79.57 | Impact Factor (2015): 6.391

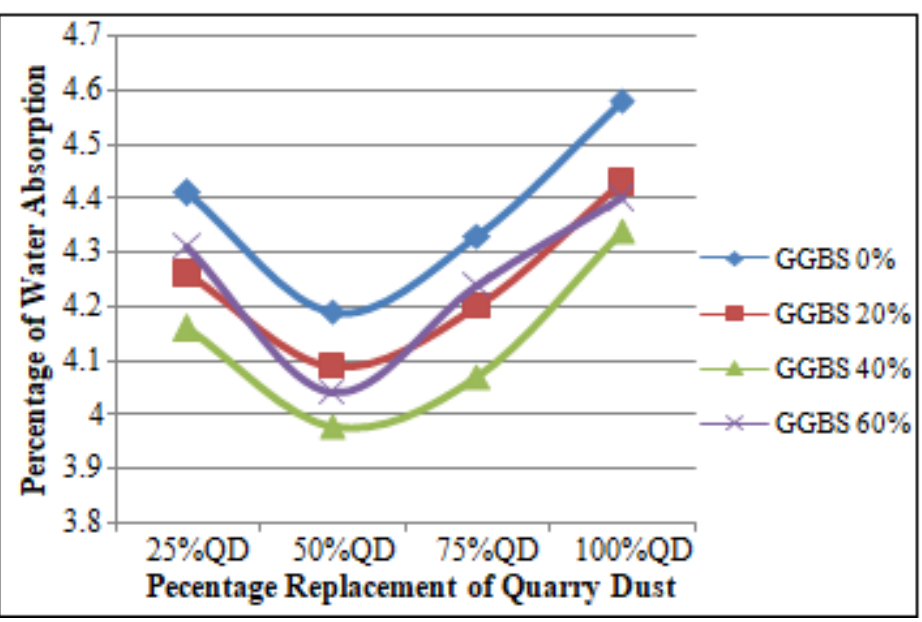

Figure 9: Variation of percentage Water Absorption for different percentages of QD and GGBS

From the Fig.9 it is observed that the Water Absorption decreases from $25 \%$ to $50 \%$ of Quarry dust. Beyond the optimum replacement percentages water absorption increases due to the presence of more dust particles.

\section{Conclusions}

- From the test results, an increment of $18 \%$ in Compressive Strength at 28 days is observed with $40 \%$ GGBS and $50 \%$ Quarry Dust.

- The maximum percentage increase of $23.5 \%$ in Split Tensile Strength compared to control concrete and it is obtained at $40 \%$ GGBS and $50 \%$ Quarry Dust replacement.

- The maximum percentage increase of $29 \%$ in Flexural Strength compared to control concrete is obtained at $40 \%$ and $50 \%$ replacements of Cement and Fine Aggregate with GGBS and Quarry Dust respectively.

- At $40 \%$ and 50\% replacement with GGBS and Quarry Dust respectively, Modulus of Elasticity of Concrete is 31.5 GPa where as Control Concrete has Modulus of Elasticity of 27.4GPa.

- At a replacement percentage of $40 \%$ cement with GGBS and fine aggregate with $50 \%$ Quarry Dust, the Water Absorption has the minimum value.

- Finally it is very interesting to note that the variation of various test results followed the similar trend.

\section{References}

[1] IS: 10262-2009. Concrete Mix Proportioning Guidelines (First Revision). Bureau of Indian Standards, New Delhi.

[2] IS 516:1959. Methods of Tests for Strength of Concrete, Bureau of Indian Standards, New Delhi, India.

[3] IS: 12269:1987. Specification for 53 Grade Ordinary Portland Cement-Specifications. Bureau of Indian Standards, New Delhi.

[4] IS 456-2000. Plain and Reinforced concrete code for practice. Bureau of Indian Standards, New Delhi (India).

[5] IS: 383:1970 (Reaffirmed 1997) Specification for Coarse and Fine Aggregates from Natural Sources for Concrete. Bureau of Indian Standards, New Delhi

[6] Oner A. Akyuz S. and Yildiz. R. (2007). An experimental study on strength development of concrete containing fly ash and optimum usage of fly ash in concrete, Cement and Concrete Research 35, pp. 1165 1171.

[7] Shariq, M., Prasad, J., and Ahuja, A.K. (2008). "Strength Development of Cement Mortar and Concrete Incorporating GGBFS". Asian Journal of Civil Engineering (Building and Housing), 9 (1), 61-74 .

[8] Peter W.C. Leung, and Wong, H.D. (2010). "Final Report on Durability and Strength Development of Ground Granulated Blast Furnace Slag Concrete". Geotechnical Engineering Office, Civil Engineering and Development Department, The Government of Hong Kong.

\section{Volume 6 Issue 12, December 2017}

\author{
www.ijsr.net
}

